Winter 2008

\title{
Customary Transnational Law: Attacking the Last Resort of State Sovereignty
}

Till Müller

University of Kiel

Follow this and additional works at: https://www.repository.law.indiana.edu/ijgls

Part of the Civil Law Commons, and the International Law Commons

\section{Recommended Citation}

Müller, Till (2008) "Customary Transnational Law: Attacking the Last Resort of State Sovereignty," Indiana Journal of Global Legal Studies: Vol. 15 : Iss. 1 , Article 3.

Available at: https://www.repository.law.indiana.edu/ijgls/vol15/iss1/3

This Symposium is brought to you for free and open access by the Law School Journals at Digital Repository @ Maurer Law. It has been accepted for inclusion in Indiana Journal of Global Legal Studies by an authorized editor of Digital Repository @ Maurer Law. For more information, please contact rvaughan@indiana.edu.

\section{$\Psi$}

JEROME HALL LAW LIBRARY

INDIANA UNIVERSITY

Maurer School of Law
Blooming ton 


\title{
Customary Transnational Law: Attacking the Last Resort of State Sovereignty
}

\author{
TILL MÜLLER*
}

\begin{abstract}
In the Westphalian State, Customary International Law (CIL) has traditionally been informed by high-level state action among close neighbors. However, it is no longer a foregone conclusion that $C I L$ is resistant to the influences of greater globalization and transnational government and non-governmental action. As the interaction among and between national governments and non-governmental organizations increases in frequency, breadth, and physical distance, we are asked to reconsider the formation of modern CIL. Ultimately, the ever increasing importance of transnational cooperation, both in traditional governance and non-governmental action, necessarily informs modern CIL. The resultant body of law may appropriately be described as Customary Transnational Law.
\end{abstract}

\section{INTRODUCTION}

The nation-state of Westphalian character is under attack! Globalization is impeding the sovereignty of the nation-state in all three of its traditional branches. Increasingly, commentators are questioning whether the Westphalian system of sovereign states will survive globalization.'

* LL.M. 2008, Indiana University School of Law-Bloomington. First State exam in Law, University of Kiel (Germany) 2006. I would like to thank Prof. Christiana Ochoa for her kind advice and support during the drafting of this paper. I would also like to thank her and Prof. Alfred C. Aman for giving me the opportunity to present my ideas at the annual symposium of the Indiana Journal of Global Legal Studies in April 2007.

1. See Saskia Sassen, De-Nationalized State Agendas and Privatized Norm-Making, in Public Governance in the Age of Globalization 51, 51-67 (Karl-Heinz Ladeur ed., 2004); Susan Strange, The retreat of the State: The Diffusion of Power in the World Economy 3-i5 (1996); Jost Delbrück, Structural Changes in the International System and Its Legal Order, 11 SZIER 1, 1-3 (2001); Karsten Nowrot, Consequences of the Changing International System: The Role of

Indiana Journal of Global Legal Studies Vol. 15 \#1 (Winter 2008)

CIndiana University School of Law 
Elected lawmakers can no longer focus exclusively on domestic concerns. Legislators in our global world have to pay heed to international obligations of their states and to international law, both of which dictate the contents of domestic law (e.g., European Community (EC) directives). ${ }^{2}$ In addition, leaders are also pressured by transnational interest groups such as Transnational Corporations [TNCs] and Non-Governmental Organizations [NGOs]. ${ }^{3}$ When drafting legislation in technical fields such as business, science, or environmental protection, legislators are dependent on the input of a few individual international experts who shape domestic legislation worldwide. ${ }^{4}$

In order to cope with today's global problems, national administrative agencies have cooperated informally with their respective counterparts all over the world. This has created a transnational network that is alienated from the direct influence of the national state. ${ }^{5}$ This means that in some instances, individual foreign experts have more influence on domestic policies than elected officials. ${ }^{6}$ Furthermore, national governments are no longer immune to the exorbitant power wielded by both TNCs and Transnational Interest Groups (TIGs).?

Even the judiciary is no longer within the exclusive domain of the sovereign nation-state. National courts show an increasing tendency to consider the decisions of international and foreign courts when faced with complicated legal issues. ${ }^{8}$ Courts within the member states of the European Convention on Human Rights (ECHR) now take into account the jurisprudence of the ECHR when

Non-Governmental Organizations in Contemporary International Law $118,118-24$ (Aug. 1998) (unpublished LL.M. thesis, Indiana University) (on file with Indiana University-Bloomington School of Law Library).

2. See David Held, Law of States, Law of Peoples: Three Models of Sovereignty, 8 Legal Theory 1, 17-20 (2002).

3. See Nowrot, supra note 1 , at 3.

4. See Fritz Ossenbühl, Die Not des Gesetzgebers im naturwissenschaftlich-technischen Zeitalter (2000); John King Gamble \& Charlotte Ku, International Law-New Actors and New Technologies: Center Stage for NGOs?, 31 Law \& PoL'y INT'z. Bus. 221, 237 (2000); Anne Röthel, Lex mercatoria, lex sportiva, lex technica-Private Rechtsetzung jenseits des Nationalstaates? 62 ÖJZ 755, 758-62 (2007).

5. See Paul Schiff Berman, From International Law to Law and Globalization, 43 Colum. J. Transnat'l L. 485, 500-07 (2005); Sassen, supra note 1, at 58-70; Anne-Marie Slaughter, Global Government Networks, Global Information Agencies, and Disaggregated Democracy, in Public Governance in the Age of Globalization 121, 122-24 (Karl-Heinz Ladeur ed., 2004).

6. See sources cited supra note 5 .

7. See Claudio Grossman \& Daniel D. Bradlow, Are We Being Propelled Towards A PeopleCentered Transnational Legal Order?, 9 Am. U. J. INT'L L. \& PoL'y 1, 7-9 (1993).

8. See Berman, supra note 5, at 503 (attributing this phenomenon in part to the building of transnational networks of judges). 
reaching their own decisions. ${ }^{9}$ Additionally, the International Criminal Court at The Hague has complimentary jurisdiction over crimes committed in more than 103 nations. ${ }^{10}$

NGOs play an increasingly important role within almost every international organization. " They facilitate, organize, and participate in international conferences that often lead to the adoption of binding treaties. ${ }^{12}$ Furthermore, NGOs monitor treaty compliance, thus shaping the contents of international obligations. ${ }^{13}$

But do these conclusions also apply to Customary International Law (CIL)? Not according to most scholars. CIL is regarded by most as the last resort of state sovereignty. Even authors who willingly embrace the notion of globalization and the deconstruction of the nation-state see no room in the doctrine of CIL for the direct participation of transnational (or non-state) actors. ${ }^{14}$

This article aims to deconstruct this classical view of CIL and analyze the effect that the continuing process of globalization has on the formation of modern CIL. First, I will outline some Realists' observations about the influence of globalization on the international legal framework. Second, I will analyze how these influences affect CIL. Finally, I will conclude with a discussion about the emergence of non-state actor participation in the creation of CIL. However, this concept is in statu nascendi, neither completely futuristic nor fully developed. Therefore, not all questions posed by the conceptual change will be fully answered. Further discussion is necessary to address all possible dogmatic and practical implications of this development.

Ultimately, the development of CIL could lead to the emergence of what I have termed in this article Customary Transnational Law. Unlike CIL, Customary Transnational Law is not limited to the customs of the community of states but is dependent on the customs of the international community at large.

9. See, e.g., Bundesverfassungsgericht [BVerfG] [Federal Constitutional Court] Oct. 14, 2004, 2 BvR 1481/04 (F.R.G.).

10. See International Criminal Court, http://www.icc-cpi.int/home.html\&l=en (listing members of the ICC) (last visited Feb. 21, 2008).

11. See Gamble \& Ku, supra note 4, at 237; Karsten Nowrot, Legal Consequences of Globalization: The Status of NGO's Under International Law, 6 Ind. J. Global Legal Stud. 579 (1999).

12. See Stephan Hobe, The Era of Globalization as a Challenge to International Law, 40 DuQ. L. REv. 655, 660 (2002).

13. See François Bugnion, The International Committee of the Red Cross and the Development of International Humanitarian Law, 5 CHI. J. INT'L L. 191, 204-16 (2004); Thilo Marauhn, Towards a Procedural Law of Compliance Control in International Environmental Law, 56 ZAÖRV 696, 709-11 (1996).

14. See infra Part II.B. 


\section{A Realist's Observation}

Globalization has influenced and changed most of the traditional paradigms associated with the Westphalian nation-state. The following section identifies the specific elements of globalization that influence the formation of CIL.

Several phenomena commonly associated with globalization are of great importance to the formation of CIL. However, for the purposes of this article, a brief overview of the relevant phenomena should suffice. Subsection A will identify and sketch out the "foundation" of globalization-the technological changes of the last decades and their relation to globalization. Subsection $\mathrm{B}$ will show how these changes led to the emergence of a global civic society. Subsection $\mathrm{C}$ will outline the great success of NGOs during this time of accelerated change. Finally, subsection D will highlight some of the impacts the above described developments had and continue to have on international law and especially the formation of CIL.

\section{A. Technological Changes}

Jessica Mathews calls the technological revolution of the last two decades "The most powerful engine of change in the relative decline of states and rise of non-state actors." 15 While this statement is fairly self-explanatory, I will examine the intricacies of her statement below.

As early as 1993, one commentator noted the increase of power of the individual vis-à-vis the state, which resulted from information technology and from the possibility of transmitting information around the world. ${ }^{16}$ The Internet is not only one of the most used sources of news and information, ${ }^{17}$ it is now even more open to the participation of individuals. Well-known media networks use their audiences as collectors of information. ${ }^{18}$ Whole encyclopedias are written by private individuals in their spare time. ${ }^{19}$ Through special Internet platforms, everyone is able to share home videos, be they serious or not, across the world. ${ }^{20}$

Similarly, on a private level the world is becoming smaller. Subcultures with

15. See Jessica T. Mathews, Power Shift, 76 Foreign Aff. 50, 51 (1997).

16. See Grossman \& Bradlow, supra note 7, at 11-13.

17. See Mary Madden, Pew Internet \& American Life, America's Online Pursuits: The Changing Picture of Who's Online and What They Do 19 (2003) (stating that $71 \%$ of American high speed internet users employ internet news sites as their primary source of information).

18. See, e.g., BBC Home Page, Have Your Say, http://news.bbc.co.uk/.

19. See, e.g., Wikipedia, www.wikipedia.com.

20. See, e.g., YouTube, www.youtube.com. 
special interests ranging from protecting the environment to collecting small pottery elephants ${ }^{21}$ are using modern mass communications to create global networks. ${ }^{22}$ Through increased transnational communication, individuals now identify more with social groups held together by mutual interests than with fellow nationals with whom they do not share a common interest. ${ }^{23}$

\section{B. Global Civic Society/Global Networks}

The new media just described has created a world in which critical news about human rights abuses, political scandals, and environmental issues in any part of the world becomes immediately available worldwide. ${ }^{24}$ This development has been met with an increasing interest of private individuals in global affairs. Individuals in modern society are far closer to everything that happens around the globe, and more importantly, they are far more interested and willing to engage in public protest concerning occurrences on the other side of the world. ${ }^{25}$ Thus, when a state commits human rights abuses, it is not only exposed to the protests of its own citizens (who frequently cannot engage in public protest), but also to millions of private individuals all across the globe. ${ }^{26}$

In addition to this generalized global civic society, information technology has created a vast amount of networking opportunities for professionals. ${ }^{27}$ As already shown in the introduction, domestic legislation and regulation are largely influenced by the work of informal governmental networks. Several transnational professional associations are able to participate in the creation and implementation of business or technical standards. ${ }^{28}$

\section{NGOs}

As already has become apparent from the brief observations made above, one crucial factor of globalization is the increasing organization of civil society into

21. See, e.g., The International Home of Elephant Collectors Society, http://everythingelephants .com.

22. See Grossman \& Bradlow, supra note 7, at 11.

23. See Berman, supra note 5, at 505.

24. See Grossman \& Bradlow, supra note 7, at 11.

25. See Nowrot, supra note 11, at 587-89.

26. See Berman, supra note 5, at 545-46.

27. See Berman, supra note 5, at 500; Sassen, supra note 1, at 58; Slaughter, supra note 5, at 121.

28. See Berman, supra note 5 , at 547. 
NGOs. However, the International Committee of the Red Cross (ICRC), one of the oldest and probably most prominent of NGOs, was influential and successful long before the above described effects of globalization occurred and even before the concept of globalization was first articulated. ${ }^{29}$ So what is new about NGOs in the time of globalization, and why should one contemplate an increased influence of NGOs on the formation of CIL?

While NGOs are not a new concept and have been successful in the past, the process of globalization has elevated their power to an entirely different level. ${ }^{30}$ Several globalization-specific developments, such as the above described evolution of a global civic society, ${ }^{31}$ are responsible for the current success of NGOs in international relations.

Another reason for the success of NGOs is the realization that many of today's most pressing problems are of a global nature and cannot be solved by each sovereign state on their own territory and terms. ${ }^{32}$ As states proved unable-often due to political unwillingness-to pressure their peers to adopt certain policies, victims of global problems did not have any opportunity other than to globalize their non-governmental effort. ${ }^{33}$ Thus issue-specific NGOs such as Greenpeace and Amnesty International have seen incredible growth and success in the past decades. ${ }^{34}$

Furthermore, the denationalization of most of the major TNCs has likewise driven private actors normally confined to national organizations to seek a transnational presence. ${ }^{35}$ TNCs are NGOs in a broader sense and are able to use their vast economic resources and power to influence states in a far greater way than the average special interest NGO. ${ }^{36}$ It must be stressed that this development would have been virtually impossible had it not been for the technical revolution in the field of telecommunications.

29. See Steve Charnovitz, Two Centuries of Participation: NGOs and International Governance, 18 Mich. J. INT'L L. 183 passim (1997) (offering an extensive historical overview of NGO participation in international governance); Nowrot, supra note 11, at 583-86.

30. See Nowrot, supra note 11, at 581-86.

31. See id. at 587-89.

32. See Grossman \& Bradlow, supra note 7, at 14-16 (focusing on how environmental issues must be addressed at the international level).

33. Id. at 8-9.

34. See Nowrot, supra note 11, at 586.

35. See Grossman \& Bradlow, supra note 7 , at 8.

36. Id. at 7-9. 


\section{Globalization and International Law}

The Introduction introduced several forces of globalization implicating the sovereignty of the nation-state. The following section will highlight a few distinct ways in which the above described effects of globalization influence the formation and content of international law and, to the extent possible at this moment, the formation of CIL.

NGOs and other non-state actors have an increasingly important influence on the negotiation and conclusion of multilateral treaties. ${ }^{37}$ For example, NGOs participated as lobbyists as well as technical experts in the conference leading to the 1982 United Nations Convention on the Law of the Sea and were able to shape the outcome. ${ }^{38}$ Further international treaties with clear non-state actor participation throughout the drafting process include the Convention on International Trade in Endangered Species, the World Heritage Convention, the Convention on Biological Diversity, and the Convention to Combat Desertification. ${ }^{39}$ Furthermore, the halting of negotiations on the Multilateral Agreement on Investment is widely regarded as an excellent example of the power of dissent possessed by the emerging global civic society. ${ }^{40}$

A prime example of NGO influence is the role of the ICRC.1 The ICRC is an active participant in all aspects of international law. It routinely is involved in negotiating and drafting international treaties. ${ }^{42}$ Moreover, the ICRC is the only organization monitoring compliance with humanitarian law and the prohibition of torture on a regular basis, thus decisively shaping the content of these norms. ${ }^{43}$ Finally, the ICRC is publishing an extensive work on "Customary International Humanitarian Law, ${ }^{14}$ which, given the prominent role of the ICRC in the field of

37. See, e.g., Gamble \& Ku, supra note 4, at 245-49; see Hobe, supra note 12, at 660 ; Nowrot, supra note 11 , at 591 .

38. See Gamble \& Ku, supra note 4, at 245-49.

39. See Nowrot, supra note 11 , at 591.

40. See Gamble \& Ku, supra note 4, at 253-58; M. Sornarajah, The Asian Perspective to International Law in the Age of Globalization, 5 Sing. J. INT'L \& Comp. L. 284, 299 (2001).

41. For a general overview of the work of the ICRC, see David P. Forsythe, The Humanitarians: The International Committee of the Red Cross (2005).

42. See Bugnion, supra note 13; Knut Dörmann \& Louis Maresca, The International Committee of the Red Cross and Its Contribution to the Development of International Humanitarian Law in Specialized Instruments, 5 CHI. J. INT'L L. 217 (2004).

43. See Bugnion, supra note 13 , at 204-16.

44. See 1, 2 Jean-Marie Henckearts \& Louise Doswald-Beck, Customary International Humanitarian Law (2005). 
humanitarian law, should be regarded as authoritative and will surely be used by every state official active in this field..$^{45}$

Furthermore, NGOs play an important role within the UN. Several UN bodies, especially those concerned with the protection of human rights, are in constant cooperation and consultation with NGOs. ${ }^{46}$ In 1990, the UN operated a total of ninety-two liaison offices for cooperation with NGOs. ${ }^{47}$ NGOs are also dominant forces at UN global conferences; the 1972 Stockholm Conference was visited by 113 States and 298 NGOs. ${ }^{48}$

That this involvement gives NGOs a great possibility to participate in the shaping of international law as well as international policy decisions is selfevident. However, it also shows one more avenue through which NGOs in fact directly influence the formation and content of CIL. It is largely agreed that Resolutions of the United Nations General Assembly (UNGA), especially when supported by the whole UNGA, are one source to turn to when identifying opinio juris. $^{49}$ If one accepts that view and recognizes the leading role of NGOs in introducing and formulating many major UNGA Resolutions, one has to accept that there is, on a very practical level, non-state participation in the creation of CIL.

Despite the short overview of the ways in which globalization and its effects have impacted the creation and content of international law, it can still safely be asserted that globalization has led to a new variety of mechanisms through which the individual can participate in the world of international law.

\section{Legal Implications of Increased Non-State Actor Participation in the International Legal Process with Special Regard to Customary INTERNATIONAL LAW}

As the traditional concept of CIL has been discussed at length by numerous scholars, ${ }^{50}$ this paper will only briefly outline its major concepts and problems.

45. Nicki Boldt, Customary International Humanitarian Law Vol. I, II, 48 German Y.B. InT'L L. $680,684,688$ (2005) (book review).

46. See Zdzislaw Kedzia, United Nations Mechanisms to Promote and Protect Human Rights, in Human Rights: International Protection, Monitoring, Enforcement 76, $76-77$ (Janusz Symonides ed., 2004).

47. See Chadwick F. Alger, Citizens and the UN System in a Changing World, in Global transformation: Challenges to the state system 301, 308 (Yoshikazu Sakamoto ed., 1994).

48. Id. at 311 .

49. Louis B. Sohn, Generally Accepted International Rules, 61 Wash. L. Rev. 1073, 1078 (1986).

50. See generally Anthony A. D'Amato, The Concept of Customary International Law (1971); Maurice H. Mendelson, The Formation of Customary International Law, 272 RecueIL des 
CIL, as a form of law that is as static as it is dynamic, is created through general and uniform state practice with a correlating opinio juris. ${ }^{51}$ However, this simple and almost intuitive principle of lawmaking ("you have always done so, so I expect you to behave the same in the future") creates several problems with regard to some basic principles of international law. For example, consider the issue of the persistent objector ${ }^{52}$ or powerful states dominating the process..$^{53}$

We will next turn to the question of how globalization has affected the process which leads to the emergence of CIL. I will first highlight some examples of how non-state actors participate in or influence the process. I will then look at practical approaches for dealing with the increased power of non-state actors. Finally, I will offer a conceptual rethinking of the CIL doctrine in light of non-state actor participation.

Having identified the theories of non-state actor participation, I will then address several points of possible critique before synthesizing the three different conceptual approaches and reconciling this new concept of CIL with traditional notions of custom as law. Lastly, I will address possible implications and questions of practical application.

\section{A. The Realist's Observation Again}

As the Introduction mentioned, this article is concerned with legal principles in statu nascendi. Accordingly, it is quite difficult to point out clear examples of non-state actor participation in actual cases of CIL formation. Nonetheless, this article will attempt to at least outline several examples of how non-state actors could have influenced the formation of CIL in the past.

The law of war crimes has been cited as an example of non-state actor par-

Cours 155, 198 (1998). For general challenges to the concept of CIL, see generally Jack L. Goldsmith \& Eric A. Posner, A Theory of Customary International Law, 66 U. CHI. L. Rev. 1113 (1999); J. Patrick Kelly, The Twilight of Customary International Law, 40 VA. J. INT'L L. 449 (2000).

51. See generally Alain Pellet, Article 38 , in The Statute of the International Court of Justice - A Commentary 208 (Andreas Zimmermann et al. eds., 2006).

52. See, e.g., Lynn Loschin, The Persistent Objector and Customary Human Rights Law: A Proposed Analytical Framework, 2 U. C. Davis J. INT'L L. \& Pol'y 147 (1996); J. Brock McClane, How Late in the Emergence of a Norm of Customary International Law May a Persistent Objector Object?, 13 ILSA J. INT'L \& Comp. L. 1 (1989); Ted. L. Stein, The Approach of the Different Drummer: The Principle of the Persistent Objector in International Law, 26 HARv. INT'L L. J. 457 (1989).

53. See Charles de Visscher, Theory and Reality in Public International Law 155 (P.E. Corbett trans., 1968). 
ticipation..$^{54}$ Given that the victims and offenders of war crimes are individuals, they participate in shaping the relevant practice. ${ }^{55}$ Here, however, a caveat is necessary; as the perpetrators of war crimes are usually acting as state officials, their actions could be seen as state practice. Furthermore, in this context, it seems far more important how the community of states deals with these transgressions of international law then by whom and how they have been committed.

However, the laws of internal and external conflict remain a useful example of non-state actor participation in creating CIL. The important role of the ICRC and its influential compendium of CIL has already been mentioned above. ${ }^{56} \mathrm{An}$ other observation is that the International Criminal Tribunal for the former Yugoslavia (ICTY) recognized the important role of non-state actors in that field by referring to the practice and statements of non-state actors when determining the state of CIL on internal armed conflicts. ${ }^{57}$

One of the most important observations, however, follows from the very nature of CIL as a process reliant on back and forth claims and counterclaims. The formation of CIL, even in its classical form, is an inherently communicative process. It relies heavily on the distribution of ideas and information. It seems that groups and individuals which act on a global level today will be more intimately involved in this process and thus actively participate in the formation of the output..$^{58}$

\section{B. Practical Approach}

Several authors recognize the increased influence of non-state actors on the formation process of CIL but stop short of rethinking the conceptual basis. Instead, they prefer different models of indirect participation, leaving the ultimate power to create or change CIL with the sovereign nation-state.

Karsten Nowrot describes the vast avenues of NGO participation in the formation of public policy and international law and asserts that they heavily influ-

54. See Jordan Paust, The Complex Nature, Sources and Evidences of Customary Human Rights, 25 GA. J. Int'L \& Comp. L. 147, 155 (1996).

55. Id. at 156-157.

56. See supra Part I.D.

57. See Claus Kreß, Friedenssicherungs und Konfliktvölkerrechtauf der Schwelle zur Postmoderne, 23 EuGRZ 638, 646 (1996).

58. See Stephan Hobe, Die Zukunft des Völkerrechts im Zeitalter der Globalisierung, $36 \mathrm{~A}_{\mathrm{R}} \mathrm{V} 245$, 266 (1999); Christiana Ochoa, The Individual and Customary International Law Formation, 48 VA. J. INT'L L. 119, 141 (2007) [hereinafter Ochoa, Individual]; Paust, supra note 54, at 156. 
ence the states' behavior. ${ }^{59}$ However, he does not go as far as granting non-state actors the power of direct participation. Rather, he falls back on the traditional notion of sovereignty and international law when he concludes that NGOs have not been recognized as direct contributors in the formation of CIL and therefore can only exercise indirect influence. ${ }^{60}$ In a later work concerned with the normative structure of TNC influence on legal prescription in the international economic order, he again addresses the issue of CIL. ${ }^{11}$ Nowrot concedes that the state-centric view of CIL creation is not without critique and should not be taken as an absolute principle. ${ }^{62}$ Furthermore, he accepts that Art. $38 \mathrm{I} \mathrm{lit.} \mathrm{b} \mathrm{of} \mathrm{the} \mathrm{Inter-}$ national Court of Justice statute leaves room for non-state actor participation and some practice of taking into account non-state actor opinio juris and practice. ${ }^{63}$ However, Nowrot only wants to grant the status of lege ferenda to non-state actor participation and concludes that it should not to be accepted as the law. ${ }^{64}$

On the same line John King Gamble and Charlotte $\mathrm{Ku}$, who have extensively analyzed the impact of modern technology on the work and success of NGOs ${ }^{65}$ and see them as emerging new actors, ${ }^{66}$ do not engage in a conceptual rethinking of CIL. Instead, they fall back on the traditional view of "states only" creation of CIL and assert indirect participation of non-state actors. ${ }^{67}$

Similarly, Michael Byers, coming from a perspective of legal personality of international law, recognizes the involvement of non-state actors in the formation of international law as important, especially through the instrument of diplomatic protection. ${ }^{68}$ But he is not able to concede any direct participation because nonstate actors lack full legal personality under international law. ${ }^{69}$

A more practical approach can be seen in Louis Sohn's description of sources of international law. He describes how international law, specifically CIL in the field of human rights, is shaped by concerned and influential individuals, rather

59. See Nowrot, supra note 11 , at 591.

60. Id. at 595 .

61. See Karsten Nowrot, Normative Ordnungsstruktur und private Wirkungsmacht 411 (2006) [hereinafter Ordnungsstruktur].

62. Id. at 412 .

63. Id. at 413 .

64. Id. at 414-15 (describing the indirect influence TNCs have on the formation of customary international law).

65. Gamble \& $\mathrm{Ku}$, supra note 4.

66. Id. at 259.

67. Id. at 243.

68. See Michael Byers, Custom, Power, and the Power of Rules, 17 Mich. J. INT'L L. 109, 155 (1995).

69. Id. 
than by states. ${ }^{70}$ Sohn explains that, in practice, state officials rely almost entirely on the works of scholars or courts-which in turn also rely on the same scholars-when determining the content of CIL. ${ }^{71}$ The overwhelming importance of scholarly and non-state issued information is evident in the compilation of CIL in humanitarian law, published by the International Committee of the Red Cross. ${ }^{72}$ However, Sohn only elaborates on these circumstances with an air of anecdotal story-telling, without a conceptual or dogmatic approach.

\section{Conceptual Approach}

Three authors have adopted a conceptual approach to address the changes brought on by globalization. ${ }^{73}$ Professor Jordan Paust has long argued for the direct participation of the individual in creating CIL, through what he calls a global expectation. ${ }^{74}$ In 1991, Professor Isabelle R. Gunning argued for a de lege ferenda inclusion of non-state actors in the formation of $\mathrm{CIL} .{ }^{75} \mathrm{Her}$ argument rests on the conviction that sometimes the ability to reach consensus can be more powerful than the power to coerce; it also rests on the factual power that non-state actors possess in a globalized world. ${ }^{76}$ The most recent proposal of a conceptual rethinking of the role of non-state actors in the creation of CIL was made by Professor Christiana Ochoa in two articles published in 2006 and 2007.77 Similar to Paust, she draws from a theoretical framework first developed by the writers of the New Haven School of International Law, establishing the international lawmaking process as one of communication between various state and non-state

70. See Louis B. Sohn, Sources of International Law, 25 GA. J. Int'L \& Comp. L. 399 (1995/96).

71. Id.

72. See supra note 44 and accompanying text.

73. Compare Hobe, supra note 58, at 266 (addressing conceptual change that would allow the participation of state actions) with Jonathan Charney, Universal International Law, 87 AM. J. INT'L L. 529 (1993) (describing a new form of customary international law).

74. Paust, supra note 54, at 155. See Jordan Paust, Customary International Law: Its Nature, Sources and Status as Law of the United States, 12 Mich. J. INT'L L. 59, 61 (1990) [hereinafter Customary Int'l Law].

75. See Isabelle R. Gunning, Modernizing Customary International Law: The Challenge of Human Rights, 31 V. J. INT'L. L. 211, 213 (1991).

76. Id.

77. See Christiana Ochoa, Towards a Cosmopolitan Vision of International Law: Identifying and Defining CIL Post Sosa v. Alvarez-Machain, 74 U. Cin. L. Rev. 105, 116 (2005) [hereinafter Ochoa, Towards a Cosmopolitan Vision]; Ochoa, Individual, supra note 58, at 140. 
actors. ${ }^{78}$ However, Ochoa also takes the view that the forces of globalization are decisive in creating new powerful non-state actors.

\section{Possible Critique}

The question of participants in the international lawmaking process is analyzed through two principles of public international law which are used frequently by scholars and politicians who are trying to exclude any direct participation of non-state actors. The first is the principle of international legal personality; in other words, the question of who can be regarded as the subject of public international law. ${ }^{79}$ The second principle, sovereignty, is often seen as reserving for states the exclusive right to create public international law. ${ }^{80}$ In addition to these basic principles of public international law, the proposed reconceptualization of CIL could also be criticized on the basis of democracy theory. ${ }^{81}$ Finally, one could doubt the factual necessity of any rethinking at all.

\section{International Legal Personality}

Many opponents of direct non-state actor participation argue that non-state actors are already excluded from any participation because they are mere objects or only partial subjects of international law. ${ }^{82}$ Although today it seems that many commentators readily accept a notion of either a very general or a very specific legal personality of non-state entities ${ }^{83}$ they still argue that non-state entities do not participate significantly in the international lawmaking process. ${ }^{84}$ Furthermore, it seems that even a large part of the commentators who accept this change

78. See Myres S. McDougal \& W. Michael Reisman, The Prescribing Function in Word Constitutive Process, 6 Yale Stud. Worl.d Pub. Ord. 249, 262, 269 (1980); Myres S. McDougal, The Hydrogen Bomb Tests and the International Law of the Sea, 49 AM. J. INT'L L. 356, 357 (1955); W. Michael Reisman, International Lawmaking: A Process of Communication, 75 Am. Soc'y INT'L L. Proc. 101 (1981).

79. The terms are used interchangeably by most scholars. See, e.g., AnNa-Karin Lindblom, Non-Governmental Organizations in International Law 75 (2005); Janne Elisabeth NiJman, The Concept of International Legal Personality 4 (2004).

80. See John W. Head, Throwing Eggs at Windows: Legal and Institutional Globalization in the 21st Century Economy, 50 U. Kan. L. Rev. 731, 733 (2002); Ivan Simonovic, State Sovereignty and Globalization, 28 GA. J. INT'L \& Comp. L 381, 384 (2000).

81. See infra Part II.D.3.

82. See Robert Redslob, Traite de Droit de Gens 71 (1950); Byers, supra note 68, at 157.

83. See Ian Brownlie, Principles of Public International Law 58 (6th ed. 2003); Antonio Cassese, International Law 142 (2d ed. 2005); Knut Ipsen, Völkerrecht $\$ 7$ (5th ed. 2004); Malcolm N. Shaw, International Law 182-95 (4th ed. 1997).

84. Byers, supra note 68 , at 157. 
do so on a very superficial and generic level without supplying substantial arguments for their conclusions. ${ }^{85}$ Therefore, this article examines the question whether individuals and other non-state actors can be regarded as subjects of international law and what that means for the right to participate in the lawmaking process.

Although there is some discussion about including further requirements such as procedural or lawmaking capacity, international legal personality is most commonly defined as the capacity to bear direct rights and obligations under international law. ${ }^{86}$ Accordingly, the next few paragraphs will evaluate the rights and obligations of non-state actors in international law, ultimately concluding that both individuals as well as NGOs are to a certain extent subjects of international law.

Due to the success of the human rights movement in the second half of the twentieth century, individuals today are protected by numerous international treaties that govern almost every aspect of their lives, and have recourse to more or less effective regional and global enforcement instruments, such as the European Court of Human Rights. ${ }^{87}$ At the same time, the increasing acceptance and development of International Criminal Law has created a direct obligation of the individual to abide by many international norms with a direct threat of persecution should these norms be violated. ${ }^{88}$ Thus the individual, as bearer of direct rights and obligations, has to be recognized as a subject of international law.

85. See Gerasimos Fourlanos, Subjectivity in International Law and the Position of the Individual, 53 Nordisk Tidsskrift Int'L Ret 9, 10 (1984).

86. See, e.g., Mario Grassi, Die Rechtstellung des Individuums im Völkerrecht 85 (1955); Michael Hempel, Die Völkerrechtsubjektivität international nichtstaatlicher Organisationen (1999); Ernst Wolf, Anfang und Ende der Rechtsfähigkeit des Menschen 128 (1955); Fourlanos, supra note 85, at 10.

87. For a detailed historical overview of the modern human rights movement and the current state of international human rights protection, see generally Martin NowaK, INTroduction to the international human rights regime (2003); Janusz Symonides, Human Rights: Concepts and Standards (2000); Janusz Symonides, Human Rights: International Protection, Monitoring, Enforcement (2003); Janusz Symonides, Human Rights: New Dimensions and Challenges (1998); Christian Tomuschat, Human Rights: Between Idealism and Realism (2003). For a statistical and substantial overview of the practice of the European Court of Human Rights, see generally Till Müller \& Kristine Franzen, Die Rechtsprechung des Europäischen Gerichtshofes für Menschenrechte im Jahre 2005, 48 German Y.в. INT'L L. 429 (2005).

88. For an account of the principles governing international crimes and an outline of international criminal trials, see generally Antonio Cassese, International Criminal Law (2d ed. 2003). For an overview of international criminal tribunals, see generally William A. Schabas, The UN International Criminal Tribunals: The Former Yugoslavia, Rwanda and Sierra Leone (2006). For a review of recent developments in international law and substantive international criminal law, see generally Gerhard Werle, Principles of International Criminal Law (2005). 
However, there are still commentators who claim that individuals have no direct rights under international law. ${ }^{89}$ Their arguments concentrate on the role that states play in the creation and enforcement of human rights. It is argued that one cannot speak of direct rights because in order to enforce these rights individuals need the consent or assistance of states. ${ }^{90}$ This consent could be recognized by the submittal of a state to the jurisdiction of an international court or by the act of transforming international law into domestic law. ${ }^{11}$ However, neither argument can be sustained. It is a basic notion of international law that conflict resolution through litigation or arbitration is subject to the consent of both parties. ${ }^{92}$ Moreover, the transformation of human rights instruments might create enforcement mechanisms in the domestic realm, but it does not influence the international obligation to protect the rights of the individual. ${ }^{93}$ As soon as a certain act committed against an individual is seen as a violation of law in the international sphere, that individual has attained a substantial right under international law, whether that right can be enforced by the individual or not. ${ }^{94}$

Other non-state actors such as NGOs or TNCs are protected by the same human rights instruments as individuals, as far as those rights apply to judicial persons, including property rights, association rights, and the right to privacy. ${ }^{95}$

89. Cf. Patrick Dumberry, L' entreprise, sujet de droit international? Retour sur la question à la lumière des dévelopments récents du droit international des investissements, 108 RevUe GENERALE DE Droit International Public 103, 111 (2004); K. P. Menon, The Legal Personality of Individuals, 6 SRI LANKA J. INT'L L. 127, 128 (1994); Alexander Orakhelashvili, The Position of the Individual in International Law, 31 CAL. W. INT'L. J. 241, 264 (2001); Edwin W. Tucker, Has the Individual Become the Subject of International Law?, 34 U. CIN. L. Rev. 341, 345 (1965).

90. See Tucker, supra note 89 , at 345 . But see Menon, supra note 89 , at 128 (acknowledging that states are no longer the exclusive subjects of international law as new entities have been admitted as actors on the international scene, and arguing that international organizations must be given a degree of international personality to make an impact on the international scene); Orakhelashvili, supra note 89 , at 264 (proposing that rules of international treaties are directly applicable to rights for individuals as the object and purpose of these treaties is to protect the individual human being rather than safeguard the interests of the state).

91. See Orakhelashvili, supra note 89, at 264.

92. See Bernd Grzeszick, Rechte des einzelnen im Völkerrecht, 43 AVR 312, 328 (2005).

93. Cf. Fourlanos, supra note 85 , at 21.

94. Karin Oellers-Frahm, Die Entscheidung des IGH im Fall LaGrand, in Die Rechtstellung des Menschen im Völkerrechr 2i (Thilo Marauhn ed., 2003); Christian Tams, Das LaGrand Urteil, 42 JUS 324, 326 (2002); Christian Tietje, Die Staatsrechtslehre und die Veränderung ihres Gegenstandes, 118 DVBl. 1081, 1085 (2003).

95. See LindBlom, supra note 79, at 137 (discussing "organization rights" held by NGOs and other organizations as a kind of "group right" ensured by human rights law); Ordnungstrukrur, supra note 61 , at 531 . For an extensive discussion of the rights of corporations under the European 
The case for obligations, however, is not as simple. Most instruments that seem to create obligations for corporations operating on a transnational level are voluntary and rely on the cooperation of the TNCs. ${ }^{96}$ Taking a contrary position, Karsten Nowrot convincingly argued that the factual position of power held by many TNCs leads to the presumption that this power is coupled with a position of obligatory legal subjectivity. ${ }^{97}$ Thus, TNCs and NGOs must also be accepted as subjects of international law.

\section{Sovereignty}

Most critics of non-state actor participation in international lawmaking see it as a substantial threat to state sovereignty. ${ }^{98}$ However, the term and concept of sovereignty is as entrenched in the discourse of international law, international relations, and political science as it is challenged, contested, and ambiguous. ${ }^{99}$ The meaning and concept of the word sovereignty is changing constantly depending on when and by whom it is used. ${ }^{100}$ Ian Ward very fittingly describes it as the grinning presence of the Cheshire Cat slipping in and out of reach to finally disappear leaving only an eerie afterthought..$^{101}$

While most critics agree that absolute sovereignty has never existed in reality and that sovereignty as a concept has proven to be an obstacle to development, ${ }^{102}$ it

Court of Human Rights, see generally Marius Emberland, The Human Rights of Companies: Exploring the Structure of ECHR Protection (2006).

96. See Lindelom, supra note 79, at 190.

97. Ordnungstruktur, supra note 61 , at $534,550,566$.

98. See Liam Burgess \& Leah Friedmann, A Mistake Built on Mistakes: The Exclusion of Individuals Under International Law, 5 MacQua RIE L.J. 221, 221 (2005).

99. See Stephen D. Krasner, Sovereignty: Organized Hypocrisy 3 (1999). See also Dan Sarooshi, The Essentially Contested Nature of the Concept of Sovereignty: Implications for the Excercise by International Organizations of Delegated Powers of Government, 25 Mich. J. INT'L L. 1107, 1108 (2004) (proposing that the concept of sovereignty can be both analyzed and qualified from the perspective of its "contested elements," such as legal versus political sovereignty, external versus internal sovereignty, indivisible versus divisible sovereignty, and governmental versus popular sovereignty).

100. See sources cited supra note 99; Winston P. Nagan \& Craig Hammer, The Changing Character of Sovereignty in International Law and International Relations, 43 Colum. J. TRANSNat'L L. 141, 143 (2004) (providing a list of different meanings given to the term sovereignty and observing that it may have different meanings to people living in different cultures, environments, and eras); Simonovic, supra note 80 , at 382 ; (stating that sovereignty is a concept that has been transformed depending on the specific circumstances of the particular time and place).

101. Ian Ward, The End of Sovereignty and the New Humanism, 55 Stan. L. Rev. 2091, 2091 (2003). 102. See Louis Henkin, Human Rights and State “Sovereignty," 25 GA. J. INT'L \& Comp. L. 31, 32 (1996); Louis Henkin, That "S" Word: Sovereignty, and Globalization, and Human Rights, Et Cetera, 68 Fordham L. Rev. 1, 1 (1999); Krasner, supra note 99, at 24; Danielle S. Petito, Sovereignty and 
also must be recognized that the concept has played a powerful role in the development of the modern world. ${ }^{103}$ As the concept itself cannot be completely dismissed, I believe that sovereignty should be accepted as what it always has been throughout its history-a conceptual description of the factual allocation of power in both international and domestic realms. ${ }^{104}$ Thus sovereignty can at the same time stabilize current allocations of power and serve as a tool for the dynamic reallocation of power. Therefore, the next step in our inquiry must be the question of factual allocation of power today.

In 1999, Professor Henkin wrote that the proponents of sovereignty as a concept of absolute state power behave "as if the concept is under siege." 105 And truly, the profound changes in international relations and global communication described above have led many authors to argue for the demise of the nation-state and the end of state sovereignty. ${ }^{106}$ The essence of all these arguments-that globalization had immense impact on the concept of sovereignty — cannot be denied. The developments since the middle of the last century have changed the allocation of power in the domestic as well as in the international realm, thus changing the content of sovereignty as an underlying principle of international relations and state theory.

The main phenomena and influences of globalization on an international and a domestic level have been outlined above. At this point, however, some more specific aspects of transnational influences on legislative processes as well as policy

Globalization, Fallacies, Truth, and Perception, 17 N.Y.L. Sсн. J. Нuм. RTs. 1139, 1146 (2001); John R. Worth, Globalization and the Myth of Absolute State Sovereignty, 79 IND. L. J. 245, 247 (2004).

103. See John H. Jackson, Sovereignty-Modern: A New Approach to an Outdated Concept, 97 Aм. J. INT'L L. 782, 789 (2003).

104. See Nagan \& Hammer, supra note 100, at 143 (listing different and overlapping meanings of sovereignty); NIJMAN, supra note 79, at 3 (illustrating different usages of the concept throughout history); Simonovic, supra note 80 , at 382 (identifying a concept of sovereignty that dates back to the sixteenth century).

105. Henkin, That " $S$ " Word, supra note 102, at 5. But see Anne-Marie Slaughter, Sovereignty and Power in a Networked World Order, 40 Stan. J. INT'L L. 283, 285 (2004) (stating that theorists, pundits, and policymakers recognize that traditional concepts of sovereignty are under assault, the result of which is an endless debate about the changing nature of sovereignty).

106. See Joseph A. Camilleri \& Jim Falk, The End of Sovereignty? The Politics of a Shrinking and Fragmenting World (1992) (exploring the continued relevance of the notion of sovereignty to an understanding of contemporary politics against the backdrop of rapid economic, technological and institutional changes which have shaped the modern world); MichaEL Ross Fowler \& Julie Marie Bunck, Law, Power, And the Sovereign State: The Evolution and A pplication of the Concept of Sovereignty (1995) (scrutinizing what constitutes a sovereign state); KraSNER, supra note 99. 
decisions will be more thoroughly examined and instances of private lawmaking will be addressed.

Anne-Marie Slaughter points out that states are no longer able to successfully address today's global problems individually; only cooperation will lead to real solutions. ${ }^{107}$ Instead of leaving states to their own devices, states now have to seek out each other and reserve the option to intervene in the affairs of another state. ${ }^{108}$ This conclusion is reflected in the rising importance of international organizations and the success of the international human rights movement. The necessity of cooperation leads to the emergence of essentially informal government networks which operate on a transnational level. ${ }^{109}$ Their activities range from exchanging information or ideas to providing technical or professional assistance to other governments or states at all levels of government (legislative, executive, and judicial). ${ }^{110}$ Without going into extensive detail, it is apparent that important decisions within any modern government are no longer independent from transnational influences. Another commentator challenges the traditional notion of sovereignty by noting that government networks usually lead to the transfer of regulatory schemes from more powerful to less powerful states. ${ }^{11}$

Professor Janet Koven Levit describes a very striking example of how private actors in today's world have taken over traditional functions of the state in prescrib-

107. Slaughter, supra note 105 , at 285.

108. See id.

109. See id. at 288; Anne-Marie Slaughter, Global Government Networks, Global Information Agencies, And Disaggregated Democracy, 24 Mich. J. InT'L L. 1041, 1043 (2003) (discussing transgovernmental regulatory networks, or more generally "government networks" which are networks of national government officials that exchange information, coordinate national policies, and work together to address common problems).

110. See Slaughter, supra note 105, at 290. See also Kanishka Jayasuriya, Globalization, Law, and the Transformation of Sovereignty: The Emergence of Global Regulatory Governance, 6 IND. J. GLobaL LEGAL STUD. 425, 446-47 (1999) (discussing the emergence of a system of regulatory networks as an important feature of governance mechanisms in the global economy, noting that as a state becomes fragmented, international regulatory agencies increasingly develop international connections, thus becoming more international in scope and function); Gerhard Loibl, The Role of International Organizations in International Lawmaking: International Environmental Negotiations-An Empirical Study, 1 Non-State Actors \& INT'L L. 41, 41 (2001) (examining the increased role of international organizations and institutions in lawmaking in the area of international environmental law, particularly in the area of ozone depletion and climate change); Anne-Marie Slaughter, Judicial Globalization, 40 VA. J. INT'L L. 1103, 1112, 1120 (2000) (explaining the potential role of judicial networks in addressing modern global problems through transnational judicial cooperation).

111. See Kal Raustiala, The Architecture of International Cooperation: Transgovernmental Networks and the Future of International Law, 43 VA. J. INT'L L. 1, 7 (2002). 
ing and enforcing legal obligations. ${ }^{112}$ She describes bottom-up lawmaking as a process originating within a homogenous, although geographically diverse, group of non-state actors, which creates extensive rules governing specific professional conduct. ${ }^{113}$ The process starts from a common practice and then involves extensive communication about substantial details. ${ }^{114}$ The resulting rules initially have the character of soft law or "gentlemen's agreements," but frequently get transformed into "real" or "hard" international law through adoption by international organizations like the Organisation for Economic Co-operation and Development(OECD). ${ }^{115}$ Specific examples for this kind of private lawmaking include the Uniform Customs and Practice (UCP) rules governing international letters of credit, which are approved and published by the International Chamber of Commerce, ${ }^{116}$ and the rules drawn up by the Berne Union concerning export insurance. ${ }^{.17}$

Again, the broad participation of NGOs and TNCs in the drafting process of multilateral treaties has to be emphasized. NGOs and TNCs participate in setting the agenda for international conferences, completing the preparatory work, and influencing the actual drafting sessions. ${ }^{118}$ The only stage they are not involved in is the actual vote. ${ }^{119}$ However, the influence on the final text is still significant, and in

112. See Janet Koven Levit, A Bottom-Up Approach to International Lawmaking: The Tale of Three Trade Finance Instruments, 30 Y ALE J. INT'L L. 125, 126-27 (2005); Janet Koven Levit, A Cosmopolitan View of Transnational Bottom-Up Lawmaking: The Case of Export Credit Insurance, 51 Wayne L. Rev. 1193, 1195 (2005).

113. See Levit, A Bottom-Up Approach to International Lawmaking, supra note 112, at 167-68.

114. See id. at $168-69$.

115. See id. at $172-73$.

116. See id. at 133-43 (arguing that although the UCP rules do not satisfy any technical definition of hard international law, the UCP rules have become functionally hard as banks and banking associations adhere strictly to the UCP rules and as domestic courts apply the UCP rules in interpreting a domestic statute designed for addressing related issues).

117. See id. at 149-57.

118. For more information regarding the participation of NGOs and TNCs in the drafting process of multilateral treaties and setting the agendas of international conferences, see OrdnungsstrukTur, supra note 61, at 214. See also Jose E. Alvarez, The New Treaty Makers, 25 B. C. INT'L Comp. L. Rev. 213, 220 (2002) (describing the scope of the 1998 negotiations in Rome establishing the International Criminal Court which involved 160 states, 33 IGOs, and over 200 NGOs); Malgosia Fitzmaurice, Actors and Factors in the Evolution of Treaty Norms, 4 ARIEL 1 (1999); (investigating the various forces influencing the development of treaties and their adaptation over time); Gamble \& $\mathrm{Ku}$, supra note 4, at 240-41 (reviewing the participation of NGOs in UN sponsored intergovernmental conferences, noting such participation in preparatory activities in particular).

119. Cf. sources cited supra note 118. 
some cases NGOs have been able to stop a treaty from being enacted..$^{120}$ Some commentators go so far as to claim that the credit for the conclusion of the Agreement on Trade-Related Aspects of Intellectual Property Rights (TRIPS Agreement) is solely owed to advocacy by TNCs organized by the Intellectual Property Committee. ${ }^{121}$ Furthermore, some TNCs and NGOs wield so much power by force of either interest generating capability or economic pressure that they are able to significantly impose their interest on governments. ${ }^{122}$ The power in the hands of TNCs is evident when one recalls that of the one hundred largest economies, fifty-one are corporations. ${ }^{123}$ Thus, with the influence of TNCs and NGOs, the nation-state has also lost its role as the sole creator of international treaties.

NGOs also play a vital role in enforcing international legal obligations through compliance monitoring and publication of human rights violations. A prime example here is the ICRC's involvement in monitoring compliance with international humanitarian law, the prohibition of torture, etc. ${ }^{14}$ In the field of human rights, NGOs like Amnesty International and Human Rights Watch play an important role in publicizing human rights violations, thus effectively contributing to the naming and shaming aspect of human rights treaties and supplying vital information for various UN procedures. ${ }^{125}$ Transparency International, a NGO combating corruption, works together with the OECD to monitor compli-

120. Cf. Gamble \& Ku, supra note 4, at 240-41 (stating that NGOs participate in treaty-making), 253-55 (detailing the cessation of MAI negotiations).

121. Cf. Susan K. Sell, Structures, Agents and Institutions, in Non-State Actors and Authority in the Global System 91, 91-92 (Richard A. Higgott et al. eds., 2000) (arguing that a small number of executives from U.S. based multinational corporations imposed their private interests onto public international law).

122. See Nowrot, supra note 11, at 586-89. For examples of how TNCs influence the international norm setting process, see ORDNUNGsstruktuR, supra note 61,214-35. For examples of the power of TNCs over national monetary systems, see Jayasuriya, supra note 110, 434-37.

123. Sarah Anderson \& John Cavanagh, The Rise of Corporate Global Power (200o), available at http://www.ips-dc.org/downloads/Top_200.pdf.

124. See id. at 9.

125. Cf. Rachel Brett, Role of NGOs-An Overview, in International Human Rights Monitoring Mechanisms 845, 845-46 (Alfredsson et al. eds., 2001) (discussing the large role of NGOs in the functioning of the UN); id. at 851-54 (describing reports from NGOs); Johanna K. Eyjolfsdottir, Amnesty International: $A$ Candle of Hope, in International Human Rights Monitoring Mechanisms, 855 (Alfredsson et al. eds., 2001) (noting that Amnesty International seeks to protect human rights through activities such as monitoring, documenting, reporting and exposing human rights violations). 
ance with the OECD Convention on Combating Bribery of Foreign Public Officials in International Business Transactions. ${ }^{126}$

Already this somewhat brief collection of transnational influences in fields traditionally reserved to the single sovereign nation-state shows an undeniable shift in power. As the factual power on both the domestic and international level is no longer limited to nation-states, the principle of sovereignty will adapt and allow these new actors to participate according to their factual capacities. Therefore, it can be concluded that the principle of sovereignty does not exclude any non-state actor participation in the formation of CIL.

\section{Democracy Theory}

The perceived lack of democratic process in the creation and transposition of CIL, even in its classic form, has always troubled scholars. ${ }^{127}$ Critics argued along the lines of third party effects: "one state one vote" and democratic legitimacy. ${ }^{128}$ With the added participation of non-state actors, especially the increased participation of NGOs and TNCs which are generally not accountable to any broader constituency, ${ }^{129}$ it is easy to imagine that cries of violated democracy will only grow more fervent.

However, increased non-state actor participation could also improve the legitimacy of CIL. ${ }^{130}$ As has been shown, individuals and other non-state actors are subject to international rights and obligations. Furthermore, they have factual power on the international level. It is a basic principle of democracy that subjects should be involved in the formation of the law that is governing their behavior. ${ }^{131}$ Traditional CIL itself lacks a certain directness in the involvement of democratically legitimized participants. Opening up the process to the smallest entities that

126. Transparency International: Deutschland e.V., Geschëftsbericht 13 (2005/2006), http://www.transparency.de/fileadmin/pdfs/Ueber_TI/Geschaeftsbericht_05_06.pdf.

127. Curtis A. Bradley \& Jack L. Goldsmith, Customary International Law as Federal Common Law, 110 Harv. L. Rev. 815, 821, 857-59, 868, 871 (1997); Kelly, supra note 50, at 518-23; Ernest A. Young, Sorting Out the Debate Over Customary International Law, 42 VA. J. INT'L L. 365, 398-400 (2002). See also Phillip R. Trimble, A Revisionist View of Customary International Law, 33 UCLA L. REv. 665, 721 (1986).

128. See sources cited supra note 127.

129. See, e.g., Kenneth Anderson, The Limits of Pragmatism in American Foreign Policy, 2 CHI. J. Int'L L. 371 (2001); Kenneth Anderson, The Ottowa Convention Banning Landmines, The Role of International Non-Governmental Organizations and the Idea of International Civil Society, 11 EUR. J. INT'L L. 91, 110-20 (2000).

130. Ochoa, Individual, supra note 58, at 168 (addressing briefly the issue of democracy).

131. Leslie J. Macfarlane, The Theory and Practice of Human Rights 142 (1985) (quoting William Cobbett, Advice to Young Men and Women (1830)). 
are obligated by the norms seems only to add some legitimacy. ${ }^{132}$ Paust, for similar reasons, argues that CIL by default is the most democratic form of international law since everyone is able to participate in its creation. ${ }^{133}$

In general the direct participation of all parties involved could lead to a higher degree of legitimacy. Still, it remains an open question at this point whether or not non-state actor participation will ultimately foster or harm global democracy.

\section{Necessity}

Another point of possible critique is whether there is a need to recognize nonstate actors as direct participants in international lawmaking. One could argue that it is sufficient to recognize non-state actors' factual power as legitimate indirect influences on the lawmaking activities of states. ${ }^{134}$ The question here is whether there is a pressing need to adapt public international law; in other words, whether there is any benefit to be seen in accepting direct participation of nonstate actors.

The "practical" approaches outlined above serve well in accommodating and dealing with non-state actor influences on a short-term basis. State officials and practitioners in international law will still be able to assert and use CIL in the traditional way. However, the practical approaches fail in solving the more pressing question of the role of non-state actors in a globalized world, because these approaches fail to recognize the actual and direct influence of non-state actors. Thus, clinging to a state-centric notion of CIL only contributes to a perceived loss of democratic legitimacy of CIL. It is hard to call for compliance with a whole body of law, when at the same time a reasonable part of its source is left shrouded and is only recognized as indirect influence. Furthermore, it will be impossible to monitor and harness the influence non-state actors have on the norm-creation process of CIL, if the influence itself is not recognized.

Another important factor that cannot be ignored in this context is the need to include the new powerful international actors in the international legal framework. International law in the era of globalization has to be a law of cooperation in order to successfully adapt to new global challenges. ${ }^{135}$ Some or even most of these international players wield so much power vis-à-vis single states that even

132. Cf. Ochoa, Individual, supra note 58, at 168.

133. Jordan Paust, Customary International Law in the United States, 40 Ger. Y.B. INT'L L. 78, 92-95 (1997) (stating that CIL is the most democratic form of international law).

134. As many authors actually do. See supra Part II.D.3.

135. Cf. Hobe, supra note 58, at 279-83. 
when international law governs their behavior, enforcement through coercive measures proves rather difficult. ${ }^{136}$ Here one could point to the relation between states and TNCs, where states usually are reliant on the revenue provided by TNCs and thus are highly susceptible to pressure by these entities. ${ }^{137}$ This creates issues of enforcement of international legal norms, especially when the norms were enacted without the participation of these corporations. Thus, a more inclusive approach to international prescription seems likely to achieve a high degree of compliance with the international norms created. ${ }^{138}$

\section{E. Synthesis}

This section will synthesize a concise view of globalized CIL from the above described arguments. The three different arguments can be roughly classified the following way: Paust pursues a more dogmatic approach, relying heavily on older writings about the importance and influence of a global expectation and lawmaking as a communicative process; ${ }^{139}$ Gunning relies on the effects of globalization which have altered the notion of state sovereignty as well as increased factual participation in international relations by non-state actors; ${ }^{140}$ and Ochoa supplies us with an extensive elaboration on the question, taking into account more absolute notions of global expectations and theories of process and democracy as well as recognizing the importance of recent changes brought about by globalization. ${ }^{141}$ The truth, in this case, lies somewhere in between.

The idea of individual participation in the creation of CIL through the formation of a global expectation or global civic society certainly is not new and was not created through globalization. As far back as 1937, Lazare Koplemanas asserted that "all the subjects of law which are in close or even distant touch with international relations contribute to the formation of international custom." ${ }^{142} \mathrm{He}$ argued that custom as law has a strong sociological element exceeding the classical concept of law purely prescribed by the state as legislator. ${ }^{143}$ Thus CIL is shaped

136. See Ordnungsstruktur, supra note 61 , at 441 .

137. Id. at 444.

138. See id. at 444-47; Hobe, supra note 58, at 280.

139. See Paust, Customary Int'l Law, supra note 74, at 61; Paust, supra note 54.

140. See Gunning, supra note 75, at 2.

141. See Ochoa, Towards a Cosmopolitan Vision, supra note 77.

142. Lazare Koplemanas, Custom as a Means of the Creation of International Law, 18 BrIT. Y.B. INT'L. L. 127, 151 (1937).

143. Id. at 150-51. 
by all participants of international relations, which today also encompasses a wide array of non-state actors.

The proponents of a sociologically motivated legal scholarship argue on similar lines when they speak of a transnational legal process, which describes the way in which states and non-state actors interact in international relations and through that interaction create, shape, and apply international law. ${ }^{144}$ The process of lawmaking and law compliance is seen as a complex interaction of different factors and players not limited to prescription and enforcement by states. ${ }^{145}$ Others describe a global community process of international lawmaking in which individuals engage through various state and non-state mechanisms. ${ }^{146}$ As already described above, Paust and Ochoa ground their theories of CIL in the writings of W. Michael Reisman and Myres S. McDougal who view the international prescriptive process as a series of claims and counterclaims with the involvement of all relevant international actors. ${ }^{147}$

The importance of claims and counter claims in the formation of CIL might be illustrated by a look at the evolution of the international norm governing the width of the territorial sea. In the past, several different rules were used to determine the range of sea adjacent to the coast over which states could exercise their jurisdiction. Most of the rules were motivated by technical considerations such as the "range of visibility" or the "cannon shot" rule. ${ }^{148}$ From the end of the eighteenth century to the beginning of the twentieth century, a three mile limit gradually spread around the globe but was never unanimously accepted..$^{199}$ After World War II, a number of newly formed countries started claiming larger territorial seas, ranging up to two hundred miles in width. ${ }^{150}$ These excessive claims were of course repeatedly rejected by the majority of states. At the same time, however, no consensus could be achieved on a three mile, six mile, or twelve mile limit. ${ }^{151}$ Over time, states gradually claimed more than the "traditional" three miles of territo-

144. Harold Honju Koh, Transnational Legal Process, 75 NEB. L. Rev. 181, 183-86 (1996).

145. Id. at 203-05.

146. Harold D. Lasswell \& Myres S. McDougal, Jurisprudence For A Free Society-Studies in Law, Science and Policy, 143-50 (1992).

147. See supra Part II.C.

148. Farhad Talaie, Final Chapter in a Conflict over the Breadth of the Territorial Sea: Recognition of the Twelve Nautical Mile Limit as Declaratory of Customary International Law, INDIAN J. INT'L. L., July-Sept. 1996, at 36, 37.

149. See id. at 37-38 (stating that the claimed limit ranged from four to six miles).

150. Id. at 39 .

151. Id. at 39-45. 
rial sea, leveling off at twelve miles today. ${ }^{152}$ The percentage of states claiming a three mile zone decreased from 95 percent in 1900 to 4 percent in 1995 and the percentage of states claiming a twelve mile zone increased from 4 percent in 1930 to 83 percent in 1995. Today, it is accepted that the twelve mile zone is part of CIL. ${ }^{153}$ The development outlined above seems to be a perfect example of the communicative process described by McDougal.

One could easily imagine that in a field of law of greater interest to various non-state actors, such as human rights, non-state actors would be much more involved in this process, facilitating claims of states and even making claims for legal protection of their own interest. These claims can take the form of public protest, advocacy, or recourse to domestic or international courts claiming a violation of CIL. ${ }^{154}$

Although this inclusive process is hard to grasp and almost impossible to quantify, 155 it provides an adequate framework to analyze and justify specific influence of non-state actors on the formation and shaping of CIL. In general, one has to accept the roles of communication and global expectation in the process of international lawmaking.

These mechanisms did not have many outlets throughout what could be called the classical era of the Westphalian state. Since the advent of globalization, however, the possibilities and mechanisms of communication and forming a global expectation have increased exponentially. The technological changes described above have enabled individuals worldwide to effectively participate in the formation of a global expectation and the global communicative process that leads to the creation of international law. The global success of human rights and the accompanying change of the concept of the subject-object dichotomy of international law ${ }^{156}$ have further opened up the constitutive process of international lawmaking to the participation of the individual. ${ }^{157}$

It could therefore be concluded that although individual participation was

152. Id. at $41-43$.

153. Id. at 63.

154. See Ochoa, Individual, supra note 58, at 155-58 (discussing the importance of individual litigation).

155. See Berman, supra note 5, at 546.

156. Regarding the question of the subject-object of international law see, e.g., MARIo Grassi, DiE Réchtstellung des Individuums im Völkerrecht 139 (1955); Rosalyn Higgins, Conceptual Thinking About the Individual in International Law, 24 N.Y. L. Sсн. L. Rev. 11, 13 (1979); George Manner, The Object of the Individual in International Law, 46 AM. J. INT'L L. 428, 444 (1952).

157. Lung-Chu Chen, An Introduction to Contemporary International Law-A Policy Oriented Perspective 76 (1989). 
dogmatically possible throughout the classical era, it was largely dormant due to a lack of mechanisms and interest of society. Only globalization and the emergence of a new global civic society (or in Professor Ochoa's words, a cosmopolitan identity) have revived individual participation and also have created the need to find new mechanisms to accommodate the increased interest of society to participate in the creation of international law. ${ }^{58}$

\section{F. Consolidation with Traditional Concept of Custom as Law}

As illustrated above, the practical approach to globalized CIL does not constitute a long-term solution. Ochoa has supplied a convincing synthesis of the Paust and Gunning approach, which leaves open the reconciliation of Ochoa's concept of globalized CIL with the original or classical dogma of state-made CIL.

Such reconciliation has to start from the traditional concept of custom as law. Seen as a general source of law, domestic or international, custom embodies a long-standing, uniform practice which led to a general expectation that the actor would in the future behave in the same way and was obliged to do so. ${ }^{159}$ Legal obligation and pure courtesy would accordingly be distinguished only by the level and content of public expectation. ${ }^{160}$

This general principle of law has been transferred to the international sphere by classical scholars when defining the character and nature of CIL. ${ }^{161}$ Today, the actions of states could constitute practice and expectation, or opinio juris. The actions did not have to be held by a community of individuals but by the community of states. ${ }^{162}$ As international law at that time concerned only questions of interstate actions and disputes, ${ }^{163}$ the limitation to state practice and state expectation was only logical.

However, this notion of sovereignty as well as international law has long since been dispelled. Individuals are protected by a vast amount of international human rights, rooted both in treaties and CIL. They can bring claims against states for

158. See Ochoa, Towards a Cosmopolitan, supra note 77 , at 127 ; see also Gunning, supra note 75 , at 227.

159. Leopolo Pospisil, Anthropology of Law-A Comparative Theory 194 (1974).

160. Id.

161. Hiram E. Chodosh, Neither Treaty nor Custom: The Emergence of Declarative International Law, 26 TEx. InT'L L. J. 87, 97-105 (1991).

162. On the classical notion of CIL see inter alia Mendelson, supra note 50.

163. See id. at 13. 
the violation of international law before domestic and international courts and are regarded, at least in part, as subjects of international law. ${ }^{164}$

As shown above, sovereignty is not what it used to be. Non-state actors have taken over a majority of the classical responsibilities of the state and participate in legislation, policy making, and the process of international affairs. ${ }^{165}$

When one recognizes the changed role of individuals and states in international law and accepts the view that international law is no longer a purely interstate affair, the transfer of the principle of custom must also be adjusted to the new circumstances. CIL creates rights and obligations for non-state actors. Nonstate actors are active in all fields of international law as scholars, experts, victims, violators, lobbyists, or monitors. A truthful transposition of the principle of custom has to take into account all actors and subjects of international law. ${ }^{166}$

This argument makes even more sense when the focus is shifted from general domestic customary law to the more common specific customary law. For example, for the creation of a customary right of way there is no need for general acceptance by the whole community, rather only the acceptance of everyone involved and affected by the right of way is necessary. The same can be said for CIL. Now that non-state actors are fully accepted as having rights and obligations under international law, they must participate in the creation of those norms.

\section{G. Possible Implications and Problems of Practical Application}

\section{Implications}

There are several fears associated with the increase of non-state actor participation in the formation of CIL. For example, it could be that non-state actor participation would lead to a significant increase in CIL limiting the action of states, thus impairing the flexibility that allows states to address certain problems. On the other end of the spectrum, one could imagine that a small group of individuals could, through their dissent, either hinder the emergence of a norm or at least act as persistent objector for their region of the world.

Regarding the potential for an increased number of CIL norms, it has to be noted that by raising the numbers of participants, uniform practice and opinio

164. Ochoa, Towards a Cosmopolitan Vision, supra note 77, at 119-21.

165. But see supra Part II.D.2.

166. That principle led K. Venkata Raman in 1976 to assert that " $[c]$ ustom is ... the most democratic form of lawmaking. . . " Toward a General Theory of International Customary Law, in Toward World Order and Human Dignity-Essays in Honor of Myres S. McDougal 365, 378 (Michael W. Reisman \& Burns H. Weston eds., 1976). 
juris will be more difficult to achieve. Furthermore, one must keep in mind that while non-state actors gain importance, states are still the primary and most powerful players on the international level. Thus, it is more likely that we will see fewer CIL norms in the future.

The opposite scenario is rather unlikely. In order to satisfy the requirement of general and uniform practice, as well as opinio juris, absolute unanimity of all participants is not necessary. ${ }^{167}$ The more participants there are the less important the dissent of a small group. Furthermore, the concept of the "persistent objector" itself is problematic and not fully accepted. ${ }^{168}$ It is even less clear how it would transfer to non-state actor participants.

It does not seem likely that the acceptance of non-state actor participation would lead to a landslide change in CIL. ${ }^{169}$ It could be anticipated that it will be easier for judges to determine the exact content of a human right under CIL if they are allowed to take open recourse to empirical documents provided by, for example, Human Rights Watch or Amnesty International. ${ }^{170}$

\section{Identifying the Nature of the Subjective and Objective Element}

Both Paust and Ochoa seem to view a normative global expectation as a formative element of CIL. ${ }^{171}$ As this expectation has to be located within the subjective element of CIL, the question is what form the objective element is to take. In the human rights context, one could think of at least two variations. Concerning purely defensive rights, such as the prohibition of torture, the only relevant practice can be seen in public protest, i.e. the expression of a normative expectation to be free from certain behavior. Concerning more active rights, such as freedom of speech, relevant practice can also be seen in the constant practice coupled with the normative expectation to be free from persecution. Note here that the expectation is only normative and not factual, even though a free speech activist might know that he or she will be prosecuted, there will still be the normative expectation that there should be no prosecution. In other fields of international law, which see powerful individual actors in contrast to a global movement, such as international trade law, the elements of the new CIL or CTL will take more conservative forms.

167. Mendelson, supra note 50, at 211.

168. See, e.g., sources cited supra note 52.

169. See Ochoa, Towards a Cosmopolitan, supra note 77, at 144-45. But see Hobe, supra note 58, at 267.

170. See Gunning, supra note 75 , at $230-32$.

171. See Ochoa, Individual, supra note 58, at 175; Paust, Customary Int'l Law, supra note 74. 


\section{Proposed Operational Frameworks}

Both Professor Gunning and Professor Ochoa (somewhat hesitantly) have offered proposals addressing how non-state actor participation could be operationalized. Gunning proposes NGO participation modeled after the United Nations Economic and Social Council (ECOSOC). ${ }^{172}$ This proposal has been criticized by Ochoa and others. ${ }^{173}$ I concur that NGO participation should be approached with caution. Ochoa elaborates on such diverse means of participation as UNGA resolutions, human rights litigation, or public surveys such as the Eurobarometer. ${ }^{174} \mathrm{I}$ will only add the thought that probably the most effective mechanism of participation is the articulation of the global public expectation through widespread newspaper commentaries and general public protest.

\section{Conclusion}

Owing to the changed role of non-state actors in international law, I chose the term Customary Transnational Law for the title of this article. It is intended to convey the idea that nations are no longer the only participants in the creation and application of CIL. In fact, individuals, NGOs, and TNCs, to whom CIL is constantly applied, are greatly contributing to the creation of customary law.

It must be reiterated that this paper is concerned with matters of international law that move and shift somewhere between lege lata and lege ferenda. It cannot yet be asserted that current international law fully accepts the direct participation of non-state actors in the formation of CIL. However, it has been shown that such influence is a fact and that it is not precluded as a matter of principle under international law. This paper attempts to address various points of criticism and shed light on questions of implications and practical application.

Of course, some questions have not been answered to the full satisfaction of neither the reader nor myself. However, these questions must be addressed and discussed no matter how troublesome the process and how nonspecific the answers might be. Important factors in international lawmaking might otherwise go undiscovered and international law itself would lose more and more legitimacy.

172. See Gunning, supra note 75, at 230-34.

173. Ochoa, Individual, supra note 58, at 146-48; Wendy Schoener, Non-Governmental Organizations and Global Activism: Legal and Informal Approaches, 4 Ind. J. Global Legal Stud. 537, 545 (1997).

174. Ochoa, Individual, supra note 58, at 176-84. 

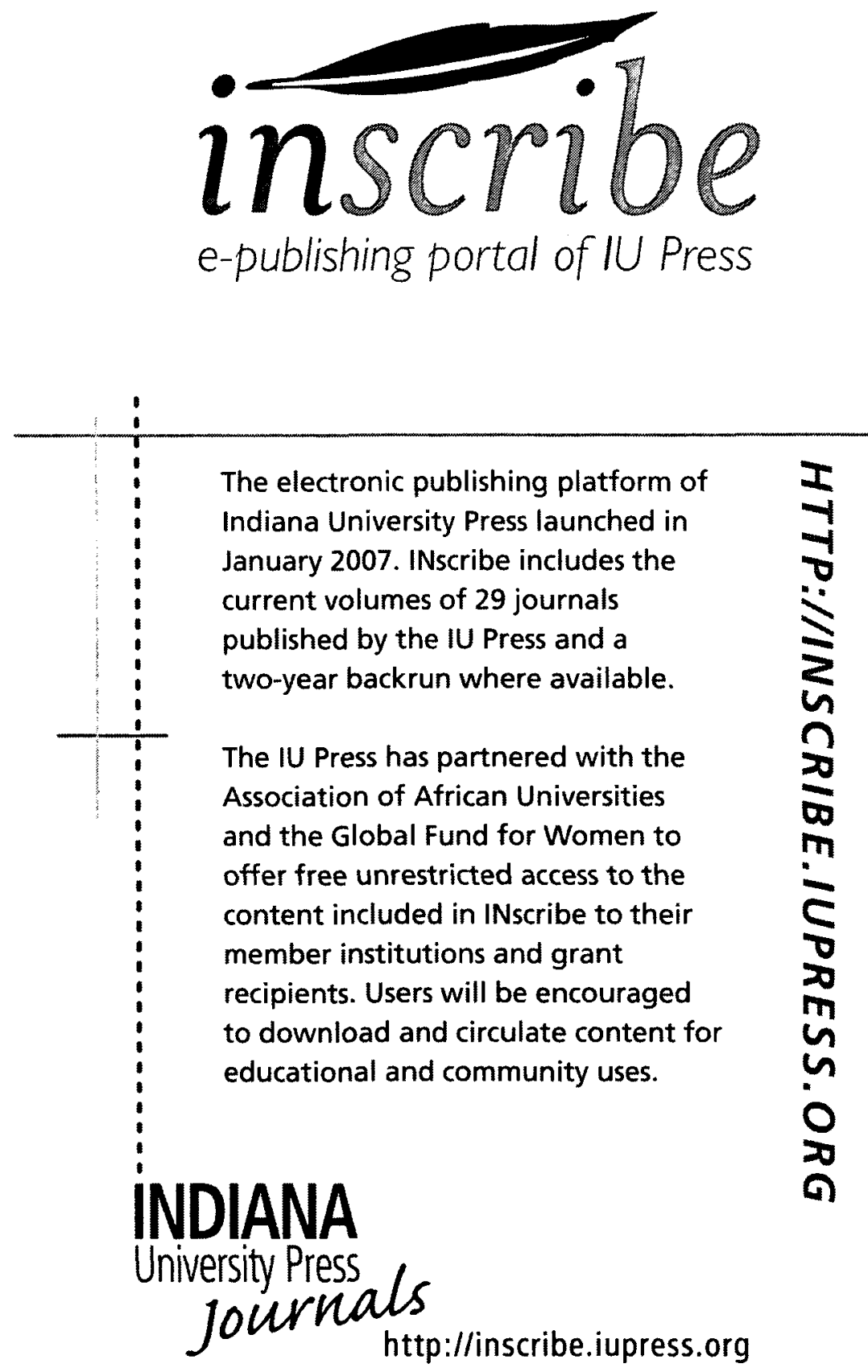